\title{
Efficiency of phylloplane bacteria in controlling aerial tomato diseases under field conditions
}

\author{
Bernardo A. Halfeld-Vieira ${ }^{1,2,}$ Reginaldo S. Romeiro ${ }^{1}$, Ann $_{\text {Mounteer }}{ }^{3}$, Eduardo S.G. Mizubuti $^{1}$
}

\begin{abstract}
${ }^{1}$ Departmento de Fitopatologia, Universidade Federal de Viçosa, 36570-000, Viçosa-MG, Brazil; ${ }^{2}$ Current address: Embrapa Roraima, BR 174, km 08, CP 133, 69301-970, Boa Vista-RR, Brazil, e-mail: halfeld@cpafrr.embrapa.br; ${ }^{3}$ Departmento de Engenharia Civil, Universidade Federal de Viçosa, 36570-000, Viçosa-MG, Brazil.

Author for correspondence: Bernardo A. Halfeld-Vieira.
\end{abstract}

Data de chegada:26/02/2006. Aceito para publicação em:24/11/2006

1332

\section{ABSTRACT}

Halfeld-Vieira, B.A., Romeiro, R.S., Mounteer, A., Mizubuti, E.S.G. Efficiency of phylloplane bacteria in controlling aerial tomato diseases under field conditions. Summa Phytopathologica, v.34, n.1, p.86-87, 2008

The capacity of two bacteria isolated from the tomato phylloplane to control late blight (Phytophthora infestans) was investigated in the field, and compared against the effectiveness of spraying with the fungicide chlorothalonil $\left(1.5 \mathrm{~g}\right.$ a.i. $\left.\mathrm{L}^{-1}\right)$ or water (control). A $55 \%$ reduction in late blight intensity was observed in the leaves of the middle of the plant and $62 \%$ in those of the upper leaves when using the antagonist UFV-STB 6
(Novosphingobium capsulatum) as compared to the control. Isolate UFV-IEA 6 (Bacillus cereus) was able to reduce disease intensity by $55 \%$, but only in the upper leaves of the tomato plants. Treatment with isolate UFV-STB 6 also led to a significant reduction in the percentage of fruits with late blight symptoms. The results demonstrate the potential of these two bacteria in controlling this disease.

Additional keywords: Biological control, Bacillus cereus, Novosphingobium capsulatum, Lycopersicon esculentum, Phytophthora infestans.

\section{RESUMO}

Halfeld-Vieira, B.A., Romeiro, R.S., Mounteer, A., Mizubuti, E.S.G. Eficiência de bactérias do filoplano no controle de doenças da parte aérea do tomateiro em condições de campo. Summa Phytopathologica, v.34, n.1, p.86-87, 2008

A capacidade de dois isolados bacterianos obtidos do filoplano de tomateiro, em controlar a requeima (Phytophthora infestans) em condições de campo, foi comparada com o fungicida chlorothalonil $\left(1,5 \mathrm{~g}^{-1}\right)$ e água (controle). Foi observada uma redução de $55 \%$ na intensidade da doença em folhas da do terço mediano da planta e de $62 \%$ nas folhas superiores, quando pulverizadas com o antagonista UFV-STB 6 (Novosphingobium capsulatum) em relação ao tratamento controle. O isolado UFVIEA 6 (Bacillus cereus) foi capaz de reduzir a intensidade da doença em $55 \%$, somente nas folhas do terço superior das plantas. As plantas pulverizadas com o isolado UFV-STB 6 também apresentaram redução significativa no percentual de frutos sintomáticos. Os resultados demonstram que os dois isolados bacterianos têm potencial no controle da doença.

Palavras chave:Controle biológico, Bacillus cereus, Novosphingobium capsulatum, Lycopersicon esculentum, Phytophthora infestans.

The tomato (Lycopersicon esculentum Mill.) is one of the world's main cultivated crops, however, many diseases limit its production potential, reducing both plant productivity and fruit quality (4). Among the different control strategies available, use of biocontrol agents may become an important component of integrated management programs. Field tests constitute an important step in the selection process of any antagonist prospecting program, since variations in humidity, temperature and solar radiation, as well as other environmental factors, may compromise a biocontrol agent's efficiency by affecting its survival capacity (1).

Use of biological control against highly destructive diseases, such as late blight $(4,5)$, caused by Phytophthora infestans (Mont.) de Bary presents a great challenge. However, biological control could become a component of integrated management, since many chemical fungicides do not by themselves afford satisfactory levels of control.

The present study was undertaken to evaluate the efficiency of two bacteria isolated from the phylloplane of tomato plants, selected in a greenhouse screening among 300 bacterial isolates (3). The efficiency was evaluated to control the late blight caused by $P$. infestans in the field.

The experiment was carried out from August 14 to October 17, 2002 at the Criciúma experimental farm near the university campus in Viçosa, Minas Gerais, Brazil. Tomato seedlings (cv. Santa Clara) were produced in styrofoam trays and transplanted to the field 30 days after planting. Plants were spaced at $0.5 \mathrm{~m}$ intervals with $0.8 \mathrm{~m}$ between rows. Fertilization was performed at the time of transplant and twenty-five days later, and was based on soil analysis. The plants were grown with single stem supported by bamboo stakes. Plants were pruned and growing stems tied to the stakes periodically throughout the experiment.

Four treatments were evaluated: the two antagonist bacteria; UFV-IEA 6 (Bacillus cereus) and UFV-STB 6 (Novosphingobium capsulatum); the fungicide chlorothalonil $\left(1.5 \mathrm{~g} \mathrm{l}^{-1}\right)$ and water (control). To prepare the antagonist suspensions, colonies were growed onto medium 523 (6) and incubated for $24 \mathrm{~h}$ at $25^{\circ} \mathrm{C}$. Cell suspensions of each bacterium were prepared in water and adjusted to $5 \times 10^{7}$ colony forming units per $\mathrm{ml}$. Spraying was initiated on the day after transplant to the field. Each treatment was applied 
weekly with a portable sprayer.

The experiment was set up in a randomized complete block design, with five repetitions. Each plot contained three rows of six plants. All assessments were made on plants in the central row.

The intensity of late blight ( $P$. infestans) was evaluated periodically (every three or four days), quantifying the percent of leaf area diseased (severity) in the upper, middle and lower leaves of each plant separately. The areas under the disease progress curves (AUDPC) were calculated.

Production was evaluated by weighing fruits from the first bunch collected separately in each plant, 64 days after transplant. The number and weight of fruits per plant and the number of fruits with late blight symptoms per bunch were counted.

Statistical analysis was carried out by the SAS program, version 8.00 , using the general linear models (GLM) procedure and the least

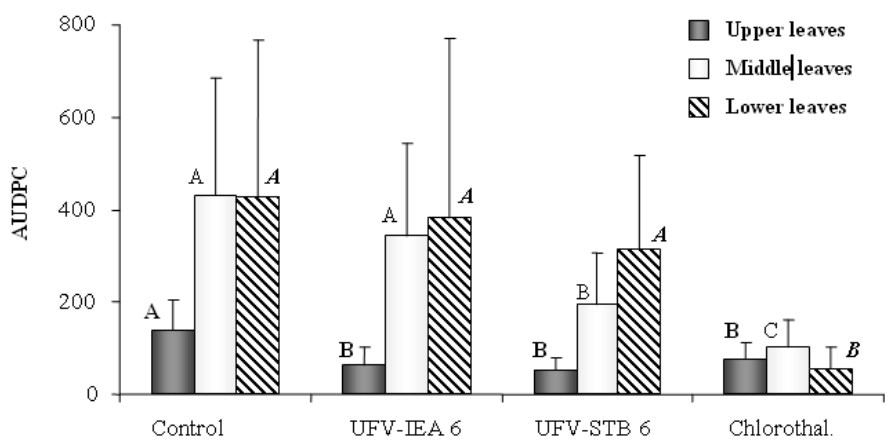

Figure 1. Comparison of different treatments for control of late blight (Phytophthora infestans) in the upper, middle and lower leaves of tomato plants, based on the area under the disease progress curve (AUDPC). Averages followed by the same letter do not differ significantly based on the Fisher-LSD test at $5 \%$ probability. Bars represent averages and error lines one standard deviation. UFV-STB $6=$ Novosphingobium capsulatum; UFV-IEA 6 = Bacillus cereus.

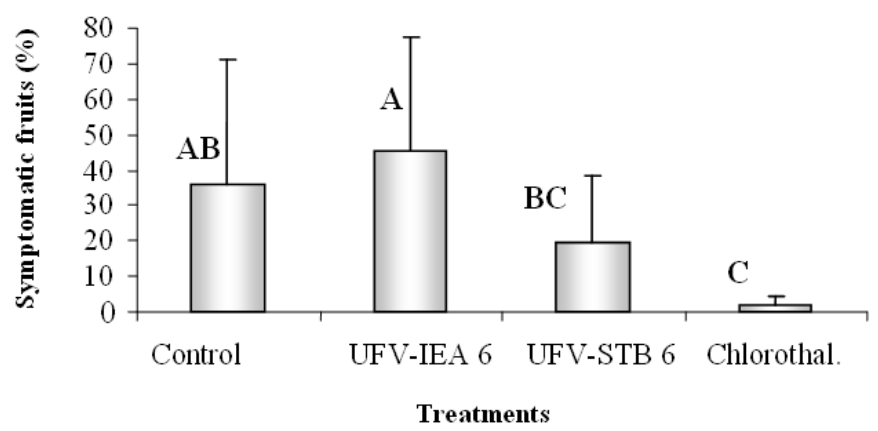

Figure 2. Comparison of different treatments for control of late blight (Phytophthora infestans) in tomato plants, based on the percentage of symptomatic fruits. Averages followed by the same letter do not differ significantly based on the Fisher-LSD test at $5 \%$ probability. Bars represent averages and error lines one standard deviation. UFV-STB $6=$ Novosphingobium capsulatum; UFV-IEA $6=$ Bacillus cereus. significant difference test (Fisher-LSD) at 5\% probability.

The efficacy of biocontrol agents in controlling late blight varied according to plant part assessed. Biocontrol agent UFV-STB 6 reduced disease intensity in the leaves at middle of plant by $55 \%$ and in the top of plant by $62 \%$, while UFV-IEA 6 had a significant result only on the upper leaves, resulting in a $55 \%$ reduction in severity of late blight. The leaves in the top of plants treated with the biocontrol agents also presented lower disease intensity than the middle and lower plant leaves (Figure 1). No biocontrol agent was capable of reducing late blight severity on lower leaves. This is probably related to the greater degree of resistance in younger leaves (2) and possibly to their being more subjected conditions less favorable to pathogen development, such as higher winds and lower humidity (5). Thus, these antagonists may contribute more effectively to reducing late blight severity in more resistant plants and in situations of lower risk of epidemic occurrence. Chlorothalonil reduced intensity of late blight as compared to the other treatments based on the AUDPC values.

No biocontrol agent reduced late blight intensity on fruits. Chlorothalonil was most efficient at reducing the percentage of symptomatic fruits per plant, followed by UFV-STB 6 (Figure 2). No significant difference in weight and number of fruits per plant was found among treatments.

A relationship was found between efficiency of disease control in leaves from different regions of the plants and the fruits of the first bunch, located at the base of the plant. Treatments that led to better late blight control in middle and lower leaves of plants also presented the lowest number of symptomatic fruits. These data indicate the necessity for a high density of inoculum to be present near the fruits for infection to occur. They may also be evidence that antagonist UFV-STB 6 is able to control the disease both in leaves and fruits.

Antagonist UFV-STB 6 was the most promise biocontrol agent against late blight. Studies on survival of the biocontrol agents under field conditions and on optimization of application frequency should be conducted, since both directly influence control capacity.

\section{REFERENCES}

1. Andrews, J.H.; Hirano, S.S. (Eds.) Microbial Ecology of Leaves. New York: Springer-Verlag, 1991. 501p.

2. Enkerli, J., Gisi, U.; Mösinger, E. Systemic acquired resistance to Phytophthora infestans in tomato and the role of pathogenesis related proteins. Physiological and Molecular Plant Pathology, London, v.43, n.3, p.161-171, 1993.

3. Halfeld-Vieira, B.A.; Romeiro, R.S.; Mizubuti, E.S.G. Comparação entre diferentes métodos de isolamento de bactérias do filoplano de tomateiro visando populações específicas e implicações na sua eficiência como agentes de biocontrole. Fitopatologia Brasileira, Fortaleza, v.29, n.6, p.638-643, 2004.

4. Hartman, G.L.; Huang, Y.H. Characteristics of Phytophthora infestans isolates and development of late blight on tomato in Taiwan. Plant Disease, St.Paul, v.79, n.8, p.849-852, 1995.

5. Jones, J.B.; Jones, J.P.; Stall, R.E.; Zitter, T.A. (Eds.) Compendium of Tomato Diseases. St. Paul: APS press, 1991. $100 \mathrm{p}$.

6. Kado, C.I.; Heskett, M.G. Selective media for isolation of Agrobacterium, Corynebacterium, Erwinia, Pseudomonas and Xanthomonas. Phytopathology, St.Paul, v.60, n.6, p.969-976, 1970. 